\title{
Sucrose-Mediated Priming of Plant Defense Responses and Broad-Spectrum Disease Resistance by Overexpression of the Maize Pathogenesis-Related PRms Protein in Rice Plants
}

\author{
Jorge Gómez-Ariza, ${ }^{1}$ Sonia Campo,, Mar Rufat, ${ }^{1}$ Montserrat Estopà,, ${ }^{2}$ Joaquima Messeguer, ${ }^{2}$ \\ Blanca San Segundo, ${ }^{1}$ and María Coca ${ }^{1}$ \\ ${ }^{1}$ Departamento de Genética Molecular, Laboratorio de Genética Molecular Vegetal, Consorcio CSIC-IRTA, Jordi Girona 18, \\ 08034 Barcelona, Spain; ${ }^{2}$ Departamento de Genética Vegetal, Laboratorio de Genética Molecular Vegetal, Consorcio CSIC- \\ IRTA, Carretera de Cabrils s/n, 08348 Cabrils, Spain
}

Submitted 16 September 2006. Accepted 21 February 2007.

Expression of pathogenesis-related (PR) genes is part of the plant's natural defense response against pathogen attack. The $P R m s$ gene encodes a fungal-inducible $P R$ protein from maize. Here, we demonstrate that expression of $P R m s$ in transgenic rice confers broad-spectrum protection against pathogens, including fungal (Magnaporthe oryzae, Fusarium verticillioides, and Helminthosporium oryzae) and bacterial (Erwinia chrysanthemi) pathogens. The PRms-mediated disease resistance in rice plants is associated with an enhanced capacity to express and activate the natural plant defense mechanisms. Thus, $P R m s$ rice plants display a basal level of expression of endogenous defense genes in the absence of the pathogen. $P R m s$ plants also exhibit stronger and quicker defense responses during pathogen infection. We also have found that sucrose accumulates at higher levels in leaves of PRms plants. Sucrose responsiveness of rice defense genes correlates with the pathogen-responsive priming of their expression in PRms rice plants. Moreover, pretreatment of rice plants with sucrose enhances resistance to $M$. oryzae infection. Together, these results support a sucrose-mediated priming of defense responses in PRms rice plants which results in broad-spectrum disease resistance.

Additional keywords: crop, Oryza sativa; sugars, transgenic plants.

Rice (Oryza sativa L.) is one of the most important cereal crops in the world, providing the principal source of calories for nearly one-third of its population. However, rice yield is severely compromised by diseases caused by pathogens. One of the most devastating diseases of cultivated rice is rice blast, caused by the fungus Magnaporthe oryzae B. C. Couch (anamorph Pyricularia oryzae) (Ou 1985). Breeding of durable resistance to this fungus is a difficult problem not only because of the high degree of pathogenic variability of $M$. oryzae but also because of the large number of fungal races encountered in the field population. The fungus Fusarium verticillioides

J. Gómez-Ariza and S. Campo contributed equally to this work.

Corresponding author: M. Coca; E-mail: mclgmb@ibmb.csic.es

* The $\boldsymbol{e}$-Xtra logo stands for "electronic extra" and indicates Figures 2, 3, 4, and 6 appear in color online.
(Sacc.) Nirenberg, formerly known as F. moniliforme J. Sheld. (Seifert et al. 2003), is also an important fungal pathogen of rice and the causal agent of the bakanae disease. This pathogen is widely distributed in Asia, although local outbreaks often can devastate the whole crop in different countries worldwide. $F$. verticillioides causes a decrease not only in quantity but also in quality of rice by producing toxins, namely fumonisins, that affect human and animal health (Nelson et al. 1993). On the other hand, rice brown spot, caused by the fungus Helminthosporium oryzae Breda de Hann occurs in all rice growing areas of the world, especially under semi-dry conditions (Ou 1985). Currently, the most common management practice for blast, bakanae, and brown spot diseases is treatment with chemical fungicides. However, the repeated use of hazardous agrochemicals for the control of these diseases has several drawbacks, such as their lack of specificity, increased incidence of development of resistance upon prolonged application, and the adverse impact on human health and environment. Another major constraint for rice production is the foot rot of rice which is caused by the gram-negative bacterium Erwinia chrysanthemi Burkholder, McFadden, \& Dimock (Goto 1979). Development of effective disease resistance to these important fungal and bacterial pathogens in rice is certainly of importance.

Plant genetic engineering provides an opportunity to introduce novel genes into rice cultivars, particularly genes conferring disease resistance. The simplest means for genetic engineering of resistance to diseases entails the expression of antimicrobial genes in transgenic plants. The expression of plant antimicrobial genes is of particular interest because they are part of the plant's natural defense system against pathogen attack. In the literature, there are many examples of increased resistance of plants toward pathogens by introduction of plant antimicrobial genes into the plant (Datta et al. 1999; Iwai et al. 2002). The outcome varies; however, resistance obtained with plant antimicrobial genes has not supported the production of new disease-resistant cultivars suitable for commercial agriculture. One of the main limitations has been the relatively low level of resistance and narrow spectrum of protection obtained with a single plant antifungal gene, which has resulted in the need to use gene combinations (i.e., simultaneous expression of chitinase and $\beta$-1,3-glucanase genes) (Jach et al. 1995; Zhu et al. 1994). A broad spectrum of protection represents a major advantage for protecting crops that are susceptible to more than one pathogen. 
The PRms protein is a pathogenesis-related (PR) protein from maize seeds whose expression is induced in response to fungal infection (Casacuberta et al. 1991, 1992). In infected maize tissues, PRms localizes to plasmodesmata (Murillo et al. 1997). Transgenic tobacco plants expressing the PRms gene exhibit resistance to phytopathogens (Cercospora nicotianae, F. tabacinum, and Phytophthora nicotianae) (Murillo et al. 2003). PRms-mediated protection of tobacco plants against these pathogens relies in the ability of PRms to alter the distribution of assimilates in the tobacco plant rather than in an intrinsic antifungal activity of this protein.

In order to assess the potential of PRms for protection of rice plants against pathogens, the PRms gene was introduced into the elite japonica rice cv. Senia. The gene was efficiently expressed under the control of the constitutive maize ubiquitin 1 promoter (ubi) and was stably inherited for at least four generations. Most importantly, transgenic rice plants showed broadspectrum disease resistance. PRms overexpression confers enhanced disease resistance in rice plants by priming stronger and quicker defense responses during pathogen infection.

\section{RESULTS}

\section{Production and molecular characterization of transgenic rice plants.}

For expression of the PRms gene in transgenic rice, a pCAMBIA-derived construct containing the PRms cDNA under the control of the maize $u b i$ promoter was prepared. Transgenic rice plants were generated by Agrobacterium-mediated transformation using the hygromicin resistance gene as the selectable marker. Integration of the PRms gene in hygromycin-resistant T0 plants was determined by polymerase chain reaction (PCR) (results not shown). Primary (T0) transformants positive by PCR analysis were assayed immunologically for the presence of PRms. For this, protein extracts were prepared from leaves of untransformed and transformed rice plants, and probed with anti-PRms antibody. PRms was detected in plants harboring the PRms gene, whereas it was not detected in untransformed control plants (Fig. 1A). No immunological reactions occurred with the protein extracts from rice plants when the pre-immune serum was used (results not shown). The PRms protein band produced by transgenic rice co-migrated with the PRms protein accumulated in $F$. verticillioidesinfected maize tissues (Fig 1A). PRms rice lines accumulating PRms at high levels (lines 14, 15, 16, 17, and 26) were selected as the parental lines to obtain T2 homozygous progeny plants.

The copy numbers and integration patterns of the transgene were determined by genomic Southern blots of the T2 homozygous progeny plants. Most of the plants analyzed showed one to two integration events (Fig. 1B). Three lines (15, 17, and 26) were selected for further studies. The unique hybridization patterns observed in these lines indicated that each line resulted from independent transformation events. The stability of transgene expression was monitored through successive generations of the selected PRms rice lines by Western blot analyses (Fig. 2E shows accumulation of PRms at the T2 generation).

\section{Enhanced disease resistance of $P R m s$ rice plants to fungal pathogens.}

To assess the protection afforded by the transgenic expression of PRms in rice, control and transgenic plants were tested for resistance to infection with several fungal pathogens, including $M$. oryzae, F. verticillioides, and $H$. oryzae, the causal agents of the blast, bakanae, and brown spot diseases of rice, respectively. For studies on blast resistance, the detached leaf assay initially was used. For this, leaves from PRms and control, untransformed plants were inoculated with increasing doses of $M$. oryzae spores. Development of disease symptoms was monitored visually. Differences in the degree of disease symptoms caused by $M$. oryzae between PRms and untransformed plants were observed clearly. At a concentration of inoculum of $3 \times 10^{6}$ spores, lesions on control leaves appeared 2 to 3 days after inoculation, whereas no detectable disease symptoms were observed in leaves of PRms lines maintained under the same experimental conditions (results not shown). In control plants, these lesions developed actively. At 7 days after inoculation, leaves from control plants were visibly damaged, whereas PRms lines appeared to be much healthier (Fig. 2A). By using an inoculum of $3 \times 10^{6}$ spores $/ \mathrm{ml}$, blast lesions were absent from leaves of PRms lines 15 and 17. In the PRms-26 line, small lesions formed when the highest dose of inoculum was used, but they did not expand as seen in the control plants.

To obtain further insights into the basis of the PRms gene's effects on $M$. oryzae infection, we microscopically examined the interactions of M. oryzae on wild-type and PRms lines at a single-cell level and at early timepoints. The interaction sites were examined by both bright-field and fluorescence microscopy, the later being used to detect autofluorescence of host cells, a well-established marker of cell death that is observed during hypersensitive response (HR) (Hammond-Kosack and Jones 1996). Results are presented in Figure 2B. In the PRms lines, $52.8 \%$ of the attacked epidermal cells showed intense
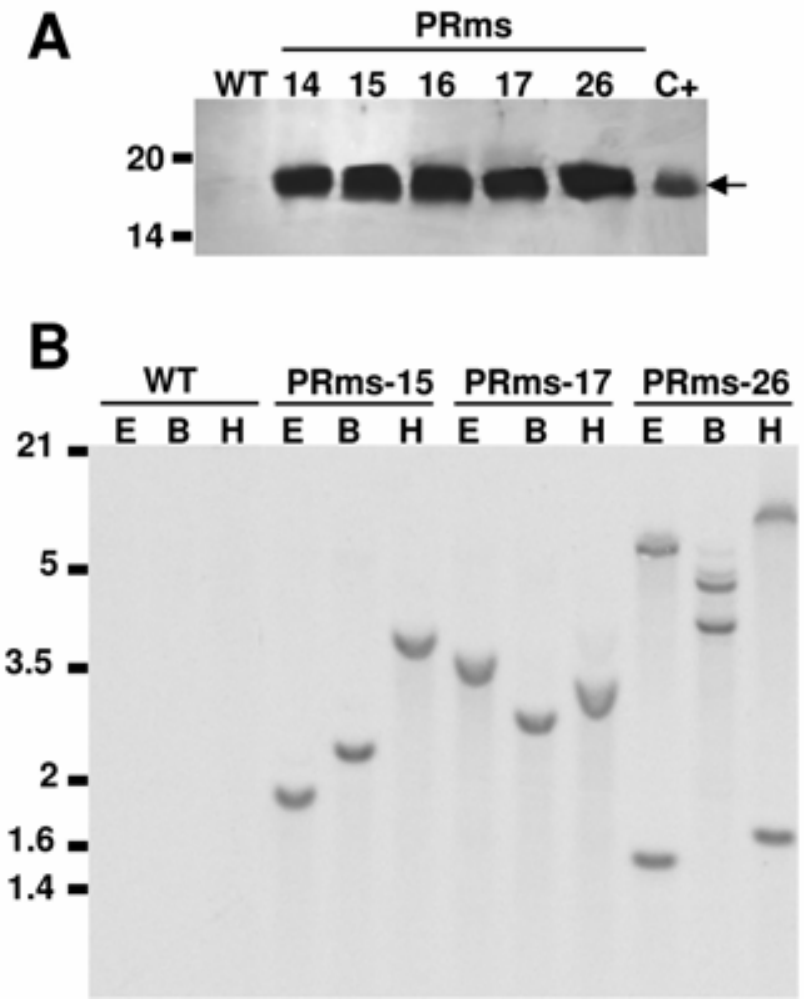

Fig. 1. Molecular characterization of PRms rice plants. A, Protein gel blot analysis of total protein extracts from leaves of PRms (lines 14, 15, 16, 17, and 26) and control (WT) rice lines. Protein extracts $(50 \mu \mathrm{g})$ were subjected to sodium dodecyl sulfate polyacrylamide gel electrophoresis and probed with the anti-PRms antiserum described by Murillo and associates (1997). Total protein extracts from Fusarium verticillioidesinfected maize seedlings were used as positive control. B, Southern blot analysis of the PRms (15, 17, and 26) and control (WT) rice plants. Genomic DNA $(10 \mu \mathrm{g})$ from T2 transgenic lines was digested with the restriction enzymes EcoRI (E), BamHI (B), and HindIII (H) and subjected to electrophoresis through a $0.8 \% \mathrm{wt} / \mathrm{vol}$ agarose gel. DNAs were transferred to nylon membrane and hybridized with the ${ }^{32} \mathrm{P}$-labeled hptII probe. Molecular weight DNA markers are shown on the left in kilobases. 
cell wall fluorescence $24 \mathrm{~h}$ post inoculation (Fig. 2B, panels c to $\mathrm{f}$ ). The number of epidermal cells displaying autofluorescence in wild-type plants was consistently lower than that of PRms lines. At $24 \mathrm{~h}$ post inoculation, $9.4 \%$ of the challenged epidermal cells showed autofluorescence in wild-type plants (Fig. 2B, panels a and b).
Trypan blue staining and microscopical observations of $M$. oryzae-infected rice leaves at 7 days after inoculation revealed extensive colonization by mycelium in the leaf tissue of control plants (Fig. 2C, panel a). The fungus produced conidia on the infected leaves of control plants (Fig. 2C, panel b). Under the same experimental conditions, no hyphae or hyphae show-
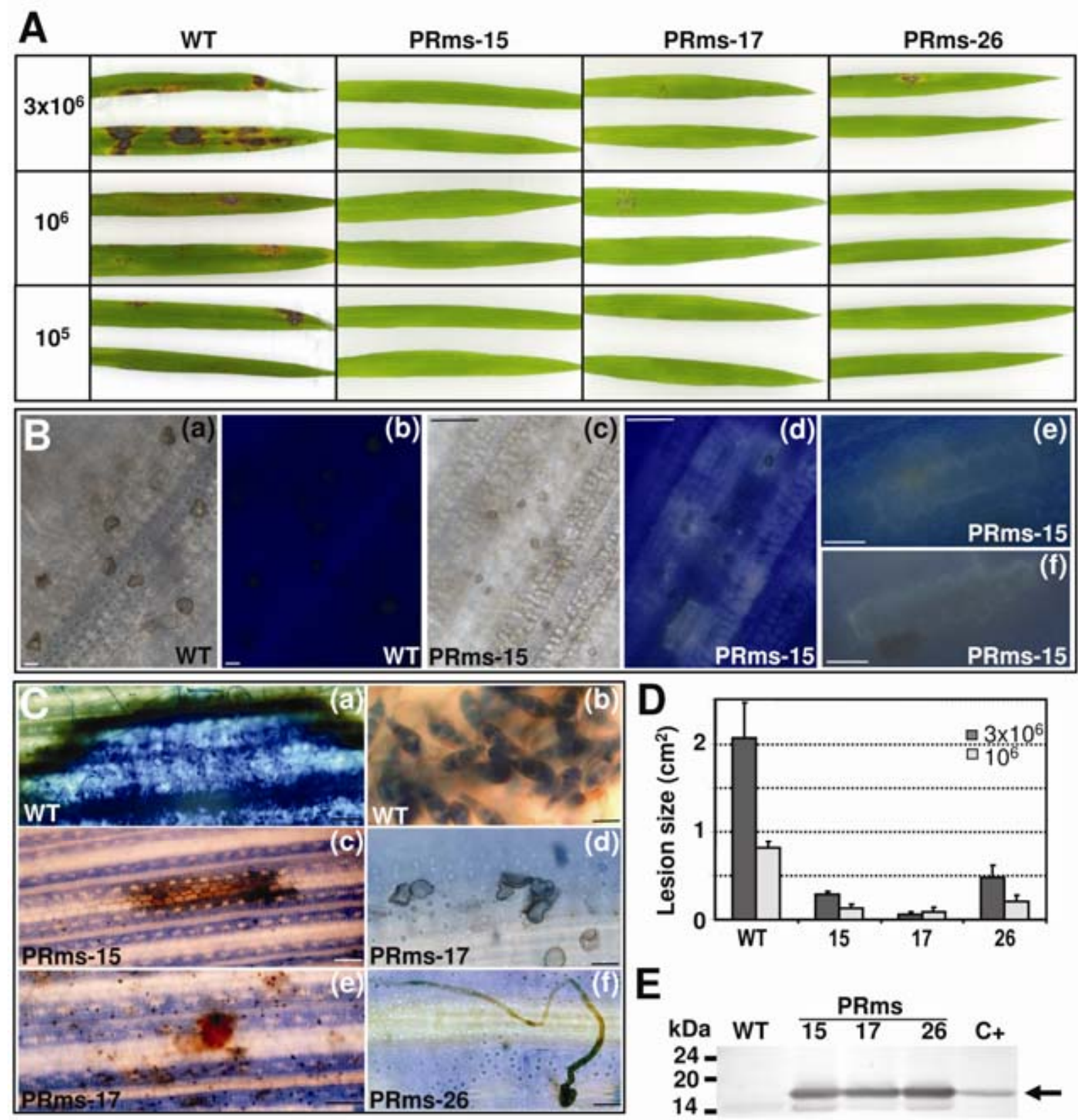

Fig. 2. Resistance of rice plants expressing the PRms gene to Magnaporthe oryzae. Resistance was tested in three independent transgenic lines (T2 generation, lines 15, 17, and 26) using the detached leaf assay. A, Leaves from control untransformed Senia plants (WT) and PRms rice lines were inoculated locally with $M$. oryzae spores. The concentration of inoculum is indicated on the left in spores/ml. Disease symptoms 7 days after inoculation of leaves is shown. Results shown are from one of three experiments that produced similar results. B, Representative micrographs of rice leaves inoculated with $M$. oryzae spores. Interaction sites $24 \mathrm{~h}$ after inoculations on WT (panels a and b) and PRms-15 (panels c to f) leaves viewed by bright-field (panels a and c) or fluorescence (panels b, d, e, and f) microscopy. Penetrated epidermal cells of PRms-15 plants show autofluorescence of cell walls (panels d, e, and f). Micrographs are representative of at least two independent evaluations. Bars $=10 \mu \mathrm{m}$ (panels a, b, e, and f) and 50 $\mu \mathrm{m}$ (panels c and d). C, Representative trypan blue staining of inoculated leaves. Leaves from WT plants were fully colonized by mycelium and produced spores (panels a and b) whereas, under the same experimental conditions, no hyphae or hyphae showing abnormal morphology were detected in leaves of $P R m s$ plants (panels c to f). Staining was carried out 7 days after inoculation with fungal spores. Micrographs are representative of three independent evaluations. Bars $=100 \mu \mathrm{m}($ panels a, $\mathrm{c}$, and e) and $10 \mu \mathrm{m}$ (panels b, d, and f). D, Size of lesions $\left(\mathrm{cm}^{2}\right)$ produced on the leaves of the control and PRms rice lines 7 days after inoculation with $M$. oryzae spores. Leaves were inoculated with a spore suspension at $3 \times 10^{6}$ (black bars) or $1 \times 10^{6}$ spores/ml (white bars). The average lesion area was determined from spot infections (three inoculations per leaf, three leaves per plant, and three plants per line). Bars represent standard errors. E, PRms accumulation in transgenic rice lines shown in A. Leaf protein extracts were separated by electrophoresis and transferred to nitrocellulose filters. The blotted proteins were probed with the anti-PRms antiserum (Murillo et al. 1997). Protein extracts were prepared from pools of leaves from 12 plants. 
ing abnormal morphology were detected in the leaf tissue of PRms rice plants (Fig. 2C, panels c to f). Significant differences in infected leaf area also were observed between control and transgenic plants when inoculated with $M$. oryzae spores (Fig. 2D). The area of lesion observed in the PRms lines varied with the dose of fungal inoculum used. Finally, Western blot analysis of the transgenic lines tested for disease resistance revealed that there were not significant differences in the level of PRms protein accumulation among the three independent transgenic lines used in this study (Fig. 2E). In all of these pathogen tests, control transgenic plants transformed with the empty vector (pCAMBIA 1300) showed results essentially similar to those of wild-type plants (results not shown; similar results were described previously by Coca and associates [2004]).

To verify the results obtained by using the detached leaf assay, inoculation experiments with soil-grown plants were carried out. For this, wild-type and transgenic plants were sprayed with $M$. oryzae spore suspensions. Results from these experiments show that the transgenic lines consistently performed better than controls. Differences in performance between control and transgenic plants were striking at 20 days after inoculation with $M$. oryzae spores (Fig. 3A). By this time, almost all of the control plants had died and the few surviving control plants were noticeably retarded in their growth. The PRms lines, however, remained healthy and showed little leaf damage. For the control plants, mortality was $84.4 \%$ compared with 40.0, 40.3, and $42.8 \%$ for $P R m s$ lines 26,15 , and 17 , respectively.

In a further experiment, disease severity in wild-type and PRms plants was evaluated by using a 1-to-6 scale of a standard evaluation system, where $1=$ no symptom and $6=$ typical susceptible-type lesion with no brown margin (Silué et al. 1992). At 7 days after inoculation, symptom scale 6 was observed in $61 \%$ of the scored leaves from wild-type plants. By the same time, symptom scale 1 to 2 was the typical response in most of the M. oryzae-infected leaves from PRms lines. This type of response was observed in 95,78 , and $80 \%$ of the leaves from PRms lines 15, 17, and 26 lines, respectively. Together, results obtained in blast resistance studies demonstrated that overexpression of the PRms gene confers resistance to the rice blast fungus $M$. oryzae in transgenic rice.

Resistance of PRms rice seedlings against the fungus $F$. verticillioides, a seedborne and soil-transmitted pathogen, was assayed. F. verticillioides-infected seed from the PRms-17 line showed more vigorous growth and a decrease in seedling mortality compared with seed from wild-type plants (Fig. 3B). Similar results were observed with the PRms lines 15 and 26 (results not shown).

Finally, the transgenic PRms plants also showed enhanced resistance to the fungal pathogen $H$. oryzae (Fig. 4A). At 9 days after inoculation, the leaves of the fungus-infected wildtype plants showed clear symptoms of infection and spreading of fungal hyphae, as revealed by trypan blue staining of fungal-infected leaves. In contrast, leaves of the inoculated transgenic plants had no such growth of fungal hyphae.

\section{Enhanced disease resistance}

\section{of $P R m s$ rice plants to a bacterial pathogen.}

We assessed whether PRms plants had altered resistance to the bacterial pathogen E. chrysanthemi. Ten days after infection, nontransformed seedlings showed typical symptoms of E. chrysanthemi infection, the roots becaming decayed and easily pulling off (Fig. 4B). In the surviving wild-type seedlings, the tissues of the young leaves were soft-rotted and collapsed. Transgenic lines consistently performed better than controls and grew green. Among the transgenic plants analyzed (lines 15, 17, and 26), line PRms-26 showed better control than the two other lines.

\section{The induction}

of defense-related genes after pathogen infection is faster and stronger in PRms rice plants.

We examined the expression of the endogenous defense genes in PRms rice plants. Moreover, the fungal-induced pattern of expression of the endogenous defense-related rice genes was analyzed in both control and transgenic plants. For this, total RNA was isolated from leaves of control and PRms lines 15, 17 , and 26 at different times after inoculation with $M$. oryzae spores. Total RNAs then were used for reverse-transcription (RT)-PCR experiments using gene-specific primers. Results are presented in Figure 5.
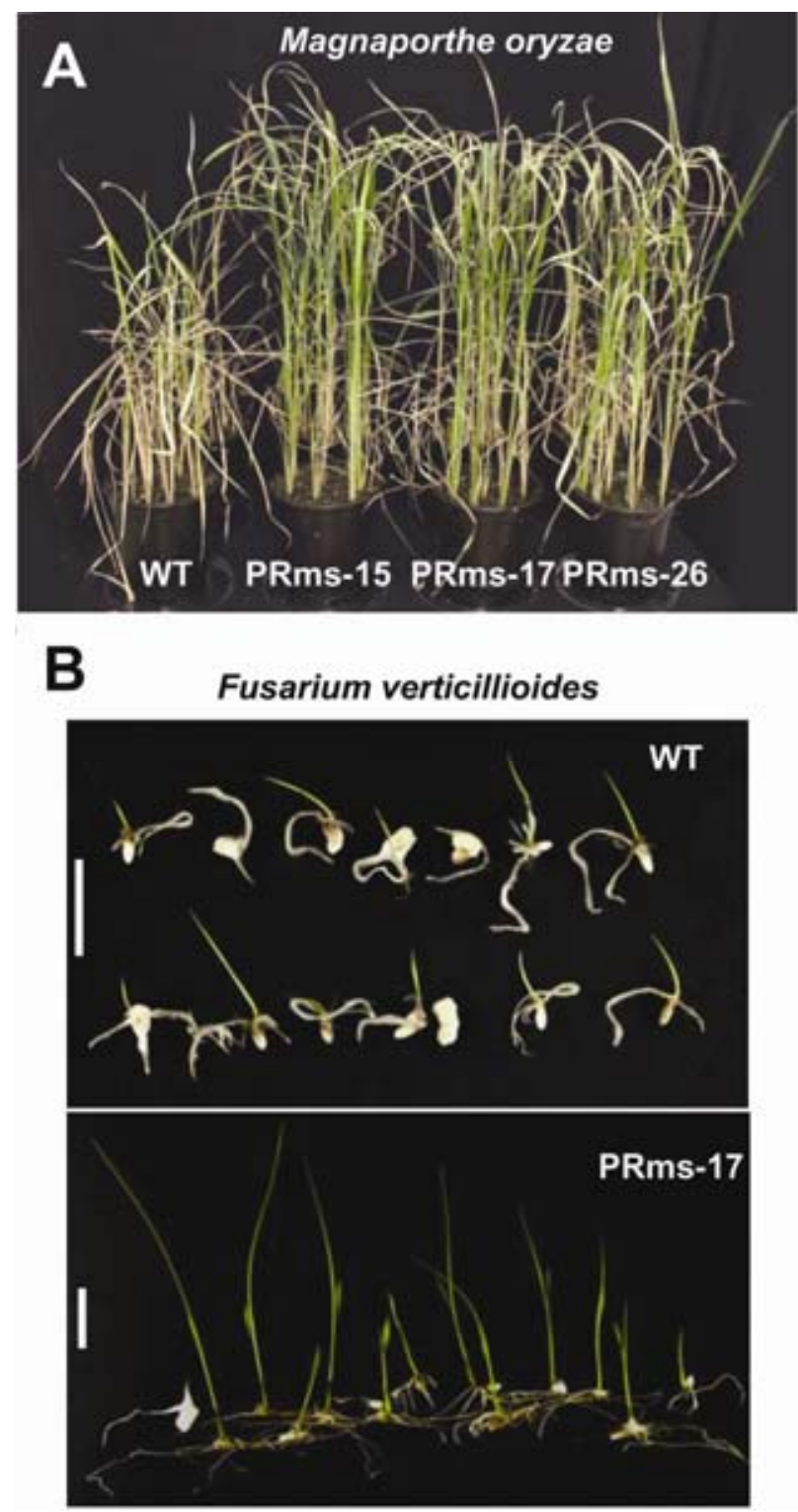

Fig. 3. Resistance of $P R m s$ rice plants to infection by the rice blast fungus Magnaporthe oryzae and by the Fusarium verticillioides fungal pathogen. A, Appearance of PRms-expressing rice lines (T2 homozygous lines) and control untransformed Senia plants (WT) challenged with M. oryzae. Plants at the three-leaf stage were sprayed with a suspension of $M$. oryzae spores $\left(10^{4}\right.$ spores $\left./ \mathrm{ml}\right)$. Picture was taken 15 days after inoculation. Results shown are representatives of three independent assays. B, Phenotypes of control (WT) and transgenic (PRms-17 line) rice seedlings infected with $F$. verticillioides. For each line, seed were germinated for $24 \mathrm{~h}$, inoculated with 50 $\mu \mathrm{l}$ of fungal spores $\left(10^{2}\right.$ spores/ml) or with sterile water, and then allowed to continue germination. Picture was taken 9 days after inoculation with fungal spores. Similar results were observed with PRms-15 and PRms-26 lines. Results shown are representatives of two independent resistance assays. 
The expression of $P R I$ genes is a widely used indicator of induction of plant defense responses. As is the case in other plant species, the PR1 family of PR proteins comprises several members in rice. The expression of two members of the rice $P R 1$ family, the OsPRIa and OsPRIb genes, whose expression has been proposed to be considered as a marker in defense or stress responses in rice, was analyzed (Agrawal et al. 2001). In fungal-infected untransformed plants, OsPRla transcripts increase at $24 \mathrm{~h}$ after inoculation, its accumulation being maintained at $48 \mathrm{~h}$ after infection. In contrast, PRms rice plants showed accumulation of OsPRIa transcripts in the absence of infection and its level of accumulation remained at constant levels regardeless of the fungal infection. Concerning the expression of the $O S P R I b$ gene, the pathogen-induced accumulation of $O s P R I b$ transcripts was detected at $24 \mathrm{~h}$ after inoculation in control plants and further increased at $48 \mathrm{~h}$ after inoculation. As was found for the OsPRla gene, PRms plants grown in noninfected conditions exhibited a basal level of expression of the endogenous $O s P R 1 b$ gene. Of interest was the fact that $O s P R I b$ expression was induced earlier and to higher levels in the $M$. oryzae-infected leaves of the PRms rice plants than in nontransformed plants. Thus, for the $O s P R I b$ gene, priming of the fungal-induced activation occurred in PRms rice plants.

Next, the expression of the the $P B Z 1$ gene, a probenazoleinducible gene from rice that encodes an intracellular PR protein (PR10 family), was examined (Fig. 5). PBZl has been identified as a defense marker that is induced in the rice- $M$. oryzae interaction (Midow and Iwata 1996). A basal level of PBZ1 gene expression was observed in transgenic lines in the absence of pathogen infection. Of interest was the fact that $P R m s$ plants exhibited a quicker response to infection as judged by the observed accumulation of $P B Z 1$ transcripts (12 $\mathrm{h}$ after infection) compared with wild-type plants (24 to $48 \mathrm{~h}$ after infection).

Results obtained on the expresion of a thaumatin-like protein (TLP), a member of the PR5 family of PR proteins, are presented in Figure 5. TLPs were shown to be induced in rice plants infected with the sheath blight fungus Rhizoctonia solani (Velazhahan et al. 1998). In both control and transgenic

\section{A Helminthosporium oryzae}

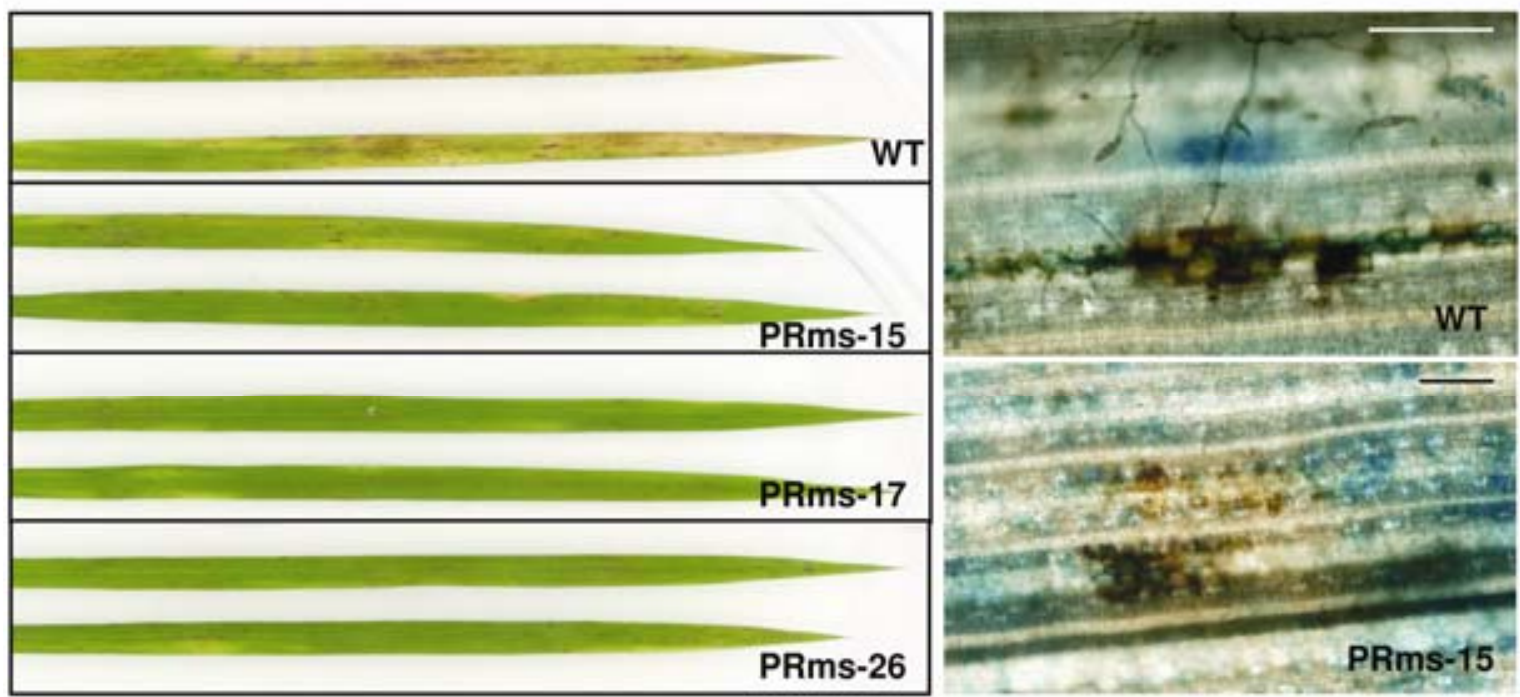

\section{B}

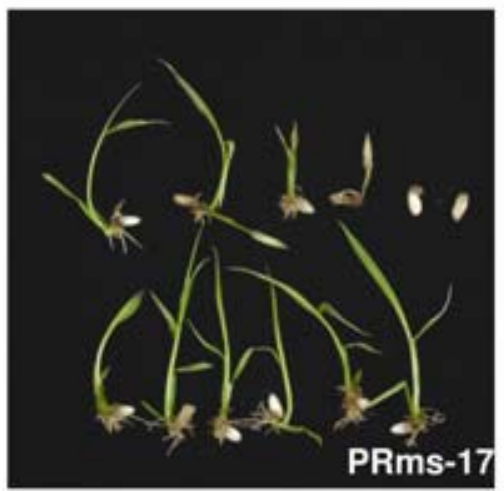

\section{Erwinia chrysantemi}

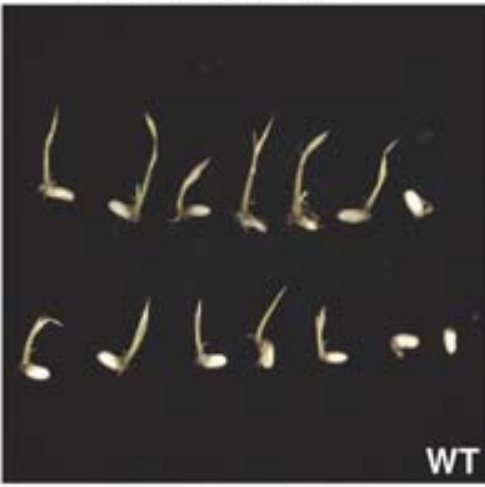

Fig. 4. Resistance of rice plants expressing the PRms gene to infection by the Helminthosporium oryzae fungal pathogen and the bacterial foot rot Erwinia chrysanthemi. Disease resistance assays were carried out at least twice with three independent PRms lines. A, Detached leaves from control (WT) and PRms rice lines $\left(15,17\right.$, and 26). Leaves were inoculated locally with a suspension of $H$. oryzae spores (10 ${ }^{5}$ spore/ml). Disease symptoms at 9 days after inoculation of leaves are shown. Right panels show representative trypan-blue staining of inoculated leaves from wild-type (WT) and transgenic (line 15) rice plants at 9 days after inoculations. Bars $=50 \mu \mathrm{m}$. B, Phenotypes of WT and PRms rice seedlings infected with E. chrysanthemi. Seed were germinated for 24 $\mathrm{h}$, vacuum infiltrated with a bacterial culture $\left(10^{6} \mathrm{CFU}\right)$ and then allowed to continue germination. Pictures were taken 10 days after bacterial infiltration. 
plants, TLP transcripts were detected at $6 \mathrm{~h}$ post inoculation and further increased at $12 \mathrm{~h}$ after infection with fungal spores. The level of TLP transcripts progresively decreased in wildtype plants (24 and $48 \mathrm{~h}$ post inoculation) whereas, in PRms plants, the fungal-induced accumulation of TLP transcripts was maintained up to $48 \mathrm{~h}$ after inoculation (the longest period of time analyzed in this work).

The induction pattern of the Scil gene, a member of the PR6 family encoding a subtilisin-chymotrypsin inhibitor from rice, also was investigated (Fig. 5). As was the case for the PR5 gene, no Scil (PRO) transcripts were detected in either control or transgenic plants in the absence of pathogen infection. In wild-type plants, a transient induction of Scil gene expression at $12 \mathrm{~h}$ after inoculation was observed. In PRms lines, induction of Scil gene expression occured earlier than in wildtype plants, being already detected at $9 \mathrm{~h}$ after inoculation.

Studies on the expression of additional defense-related genes of rice were carried out. Thus, the expression of two peroxidase genes, $P O X 22.3$ and $P O X 8.1$, was induced in response to fungal infection. For these two genes, induction during infection of rice by the bacterial pathogen Xanthomonas oryzae has been reported (Chittoor et al. 1997). The patterns of expression of the peroxidase genes were similar in fungal-infected leaves from both wild-type and $P R m s$ plants, indicating that transgenic expression of PRms does not affect the fungal-induced activation of these rice peroxidase genes (Fig. 5, results obtained for POX22.3 expression; similar results were observed for the POX 8.1 gene).

A different group of defense-related genes representing regulatory genes involved in signal transduction pathways that mediate responses to pathogens also was included in our analysis of $P R m s$ rice plants. Thus, the induction pattern of the OsNHI and OsJARl genes was analyzed. The AtNPRI (also known as NIM1) gene is a key regulator of the systemic adquired resistance (SAR) in Arabidopsis (Cao et al. 1994; Dong 2004). Evidence for a disease-resistance pathway in rice similar to the Arabidopsis AtNPRI-mediated signaling pathway has been reported (Chern et al. 2001, 2005). In our study, no changes in the pattern of the fungal-induced expression of the OsNHI gene (the orthologous gene to AtNPRl in rice) between wild-type and PRms-infected plants were observed (Fig. 5). Equally, there was essentially no difference in the pattern of induction of the OSJARI between control and transgenic plants, the JARl gene encoding an enzyme involved in the jasmonate response pathway (Staswick and Tiryaki 2004) (results not shown).

Thus, these studies reveal that specific defense-related rice genes (OsPRla, OsPRIb, and PBZ1) are constitutively expressed in PRms rice plants. Our results also show that PRms expression in rice results in faster and stronger induction of the defense-related genes $O s P R 1 b, P B Z 1$, and $S c i l$ in response to fungal infection. In the case of the PR5 gene, its expression remains at high levels for a longer period of time in PRms than in wild-type plants. However, PRms expression in rice does not affect the NPRI and JARI-mediated signaling pathways. All three independent $P R m s$ rice lines analyzed in this work gave similar results.

\section{Transgenic rice plants accumulate higher levels of sucrose in leaf tissues.}

PRms tobacco plants are known to accumulate higher levels of sucrose in leaves (Murillo et al. 2003). In this work, we investigated whether PRms rice plants accumulate sucrose in leaf tissues. Two independent PRms lines (15 and 17) were analyzed. The sucrose content was determined from leaves taken individually from plants at the four-leaf stage. The sucrose content in leaves from transgenic lines was higher than that of leaves from control lines (Fig. 6A).

\section{Sucrose induces the expression of defense genes and protects rice plants from $M$. oryzae infection.}

Knowing that leaf tissues of PRms plants accumulated higher levels of sucrose than leaves of wild-type plants, we decided to investigate the sucrose responsiveness of those defense-related genes showing constitutive expression in PRms plants or pathogen-responsive priming. Thus, the expression of the defense-related genes in rice plants hydroponically feeding on sucrose for $6 \mathrm{~h}$ was investigated. Sucrose feeding of rice through the root system resulted in accumulation of OsPRIa, OsPR $1 b, P B Z 1, P R 5$, and Scil transcripts in leaves of wild-

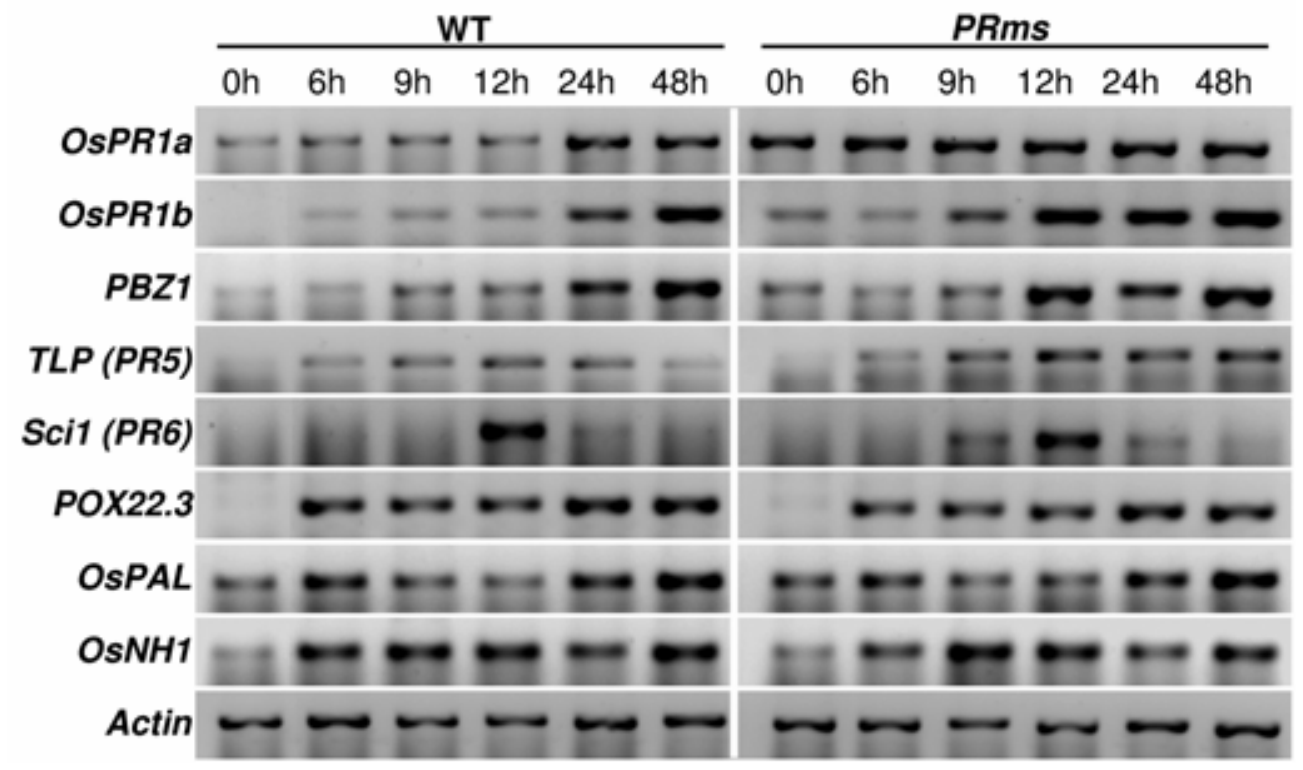

Fig. 5. Overexpression of PRms primes pathogen-induced defense gene expression. Reverse-transcription polymerase chain reaction (RT-PCR) analysis of Magnaporthe oryzae-infected leaves from control and PRms plants. Total RNA was isolated at the indicated times after inoculation. Each RNA was prepared from a pool of leaves from eight plants at the three- to four-leaf stage. RT-PCR was performed using specific primers for the indicated genes. Results for the PRms-15 are shown; similar results were obtained for the PRms-17 and PRms-26 lines. 

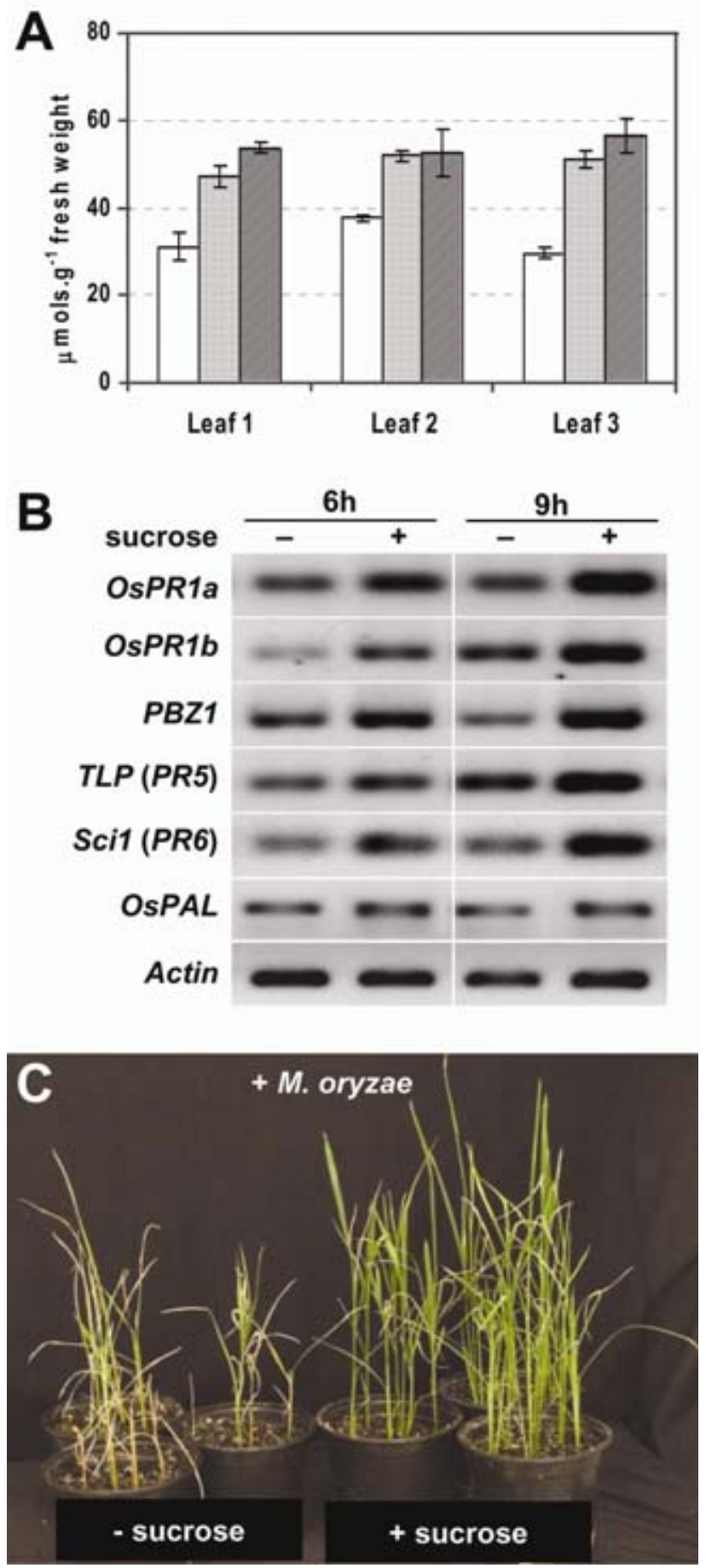

Fig. 6. Sucrose-mediated defense response in rice plants. A, Sucrose content in leaves from wild-type (white bars) and PRms rice plants (lines 15 and 17, light-gray and dark-gray bars, respectively). Leaves were harvested from 3-week-old plants (10 plants per line). The sucrose content was determined from leaves taken from the botton (leaf 1) to the top (leaf 3) (leaf 4 was discarted). Values represent the means and standard deviation of three replicas. B, Effects of hydroponic feeding of sucrose on defense gene expression. Seven-day-old rice seedlings were fed hydroponically with either Murashige-Skoog (MS) without sucrose (control) or $300 \mathrm{mM}$ sucrose for 6 or $9 \mathrm{~h}$. Total RNA was isolated from samples and analyzed by reverse-transcription polymerase chain reaction. Each RNA was a pool from leaves of at least 10 seedlings. Experiment was conducted three times with similar results. C, Pretreatment with sucrose protects rice plants from Magnaporthe oryzae infection. Wild-type plants were treated with $300 \mathrm{mM}$ sucrose for $24 \mathrm{~h}$ and then inoculated with $M$. oryzae spores. Picture was taken 15 days after inoculation. Results shown are representatives of four independent experiments. type rice plants (Fig. 6B). Sucrose failed to induce $O S P A L$ expression, which coincided with a defect in pathogen-responsive priming for expression of this gene (Fig. 5). Together, these findings support the theory that sucrose functions as a signaling molecule for induction of the expresion of these defense-related genes in rice. The basal expression and pathogen-responsive priming of defense gene expression in PRms plants correlated well with the observed sucrose responsiveness of these genes (activation of OsPRla, OsPR1b, PR5, $P B Z 1$, and Scil, but not $O s P A L$ ).

If the ability of PRms to confer plant disease resistance is due to its ability to increase sucrose levels in leaf tissues, one would expect that sucrose treatment should be active in protecting rice plants against pathogen infection. To test this hypothesis, sucrose was tested for its ability to enhance resistance to $M$. oryzae infection in rice plants. Upon soil drench treatment and spraying rice plants with $300 \mathrm{mM}$ sucrose, plants were inoculated with fungal spores. Disease symptoms then were scored in nontreated and sucrose-treated wild-type plants according to the 1-to-6 scale (Silué et al. 1992). As controls, rice plants were treated with either mannitol (300 mM) or polyethylenglicol (PEG-8000, $7 \% \mathrm{wt} / \mathrm{vol})$. At 7 days after inoculation, leaves from sucrosetreated plants either did not show any lesion (53\% of the scored leaves) or exhibited symptoms which are characteristic of scales 1 and 2 . By the same time of infection, symptom severity in most of the leaves from plants that had been treated with water, mannitol, or PEG was assigned to symptom score 4. At 15 days after inoculation, all control nontreated plants, but not sucrosetreated plants, exhibited severe disease symptoms (Fig. 6C). Overall, these observations indicated that treatment with sucrose 1 day prior to inoculation with fungal spores was sufficient to drastically reduce disease symptoms in rice plants.

\section{DISCUSSION}

Genes of agronomic importance, such as those that encode plant antimicrobial proteins that confer resistance to diseases, have been isolated from different plant species (Van Loon et al. 2006). The efficacy of these genes in improving the agronomic performance of plants usually is assayed in transgenic tobacco or Arabidopsis. The development of efficient systems for rice transformation now makes it possible to test the usefulness of these genes in protecting this important crop species. In this study, the maize PRms gene was introduced into the elite japonica rice cv. Senia. Transgenic rice plants showed stable integration and inheritance of the transgene. Most importantly, we showed that expression of the PRms gene in rice confers broad-spectrum resistance to pathogens, including fungal and bacterial pathogens. Among the three independent transgenic lines analyzed, differences in resistance to the various pathogens assayed were observed. Thus, the transgenic PRms15 and PRms-17 lines exhibited better control of $M$. oryzae, $F$. verticillioides, and $H$. oryzae than line PRms-26 (Figs. $2 \mathrm{~A}$ and D, 3A, and data not shown). The PRms-26 line, however, showed better control of the bacterial foot rot disease than the other two transgenic lines (Fig. 4B).

The expression and pattern of fungal induction of a number of defense-related genes has been examined in PRms plants showing enhanced resistance and compared with that of wildtype plants. Our studies revealed accumulation of OsPRla, $O s P R I b$, and $P B Z 1$ transcripts in PRms lines in the absence of the pathogen. For the OsPRla, OsPRIb, and PBZl genes, a role in the resistance reaction to rice blast has been described (Agrawal et al. 2001; Jwa et al. 2006; McGee et al. 2001). Additionally, earlier or stronger induction of the $O s P R-1 b$, $P B Z 1$, and Scil genes occurs in $M$. oryzae-infected transgenic lines compared with fungal-infected wild-type plants. The ex- 
pression of $P R 5$ (thaumatin-like protein) remains in an induced state for a longer period of time in fungal-infected PRms plants than in fungal-infected wild-type plants. Together, these results indicate that resistance of PRms plants is associated with an enhanced capacity to express and activate the natural plant defense mechanisms, a phenomenum known as "priming." An enhanced capacity to resist pathogen attack by stronger activation of defense responses also occurs during SAR. In this way, PRms transgenic plants would display a preconditioned resistance state comparable with SAR.

Results presented here on the microscopic analysis of $M$. oryzae-infected leaves at early timepoints of infection revealed autofluorescence in approximately $52.8 \%$ of the penetrated host cells in PRms plants. In the case of the wild-type plants, $9.4 \%$ of the penetrated cells showed autofluorescence. However, this type of response, which is reminiscent of an HR-related cell death, does not prevent penetration by the blast pathogen. Here, it should be mentioned that lignification of the first penetrated epidermal cell, as monitored by the occurrence of autofluorescence, has been shown to be the crucial defense response that accompanies resistance-gene-mediated resistance of rice to the blast pathogen (Koga 1994). Most probably, the development of an HR-related cell death at the first penetrated cells in combination with the early and strong activation of the host defense responses (priming state) could participate in arresting intracellular growth of the blast pathogen in the cells of PRms plants.

In the literature, there is information on biologically and chemically induced priming mechanisms in dicotyledoneae, namely in Arabidopsis and tobacco plants. It is well known that treatment with salicilic acid (SA) and the synthetic chemicals 2,6-dichloroisonicotinic acid (INA) and benzothiadiazole (BTH) primes defense gene expression and SAR (Kohler et al. 2002; Mur et al. 1996; Thulke and Conrath 1998). Information about the priming phenomenum in monocotyledoneae is largely missing, including the most important agronomic cereals (Kogel and Langen 2005). Thus, the monitoring of defense gene expression in PRms rice plants challenged with $M$. oryzae provided new insights into the priming phenomenon in a monocotyledoneous species.

Results presented here indicated that sucrose fed hydroponically to rice seedlings greatly primes expression of rice defense genes in leaves. Most importantly, sucrose responsiveness of the rice defense genes correlates well with the pathogenresponsive priming of their expression. Furthermore, we show that leaves of young PRms plants accumulated higher levels of sucrose than leaves of control plants. This is consistent with the previous findings that sucrose accumulates in leaf tissues of PRms tobacco plants (Murillo et al 2003). Together, these findings suggest that a high level of endogenous sucrose can be responsible for the earlier and stronger expression of the rice defense genes and support the theory that resistance in PRms rice plants is linked to sucrose signaling. Definitive proof that sucrose has a role in disease resistance in rice comes from results obtained in disease resistance studies with sucrose-treated rice plants. These results demonstrated that feeding sucrose through the root system results in transcript accumulation of defense genes in leaves. This observation confirms the implication of sucrose-dependent defense responses in the protection of rice against $M$. oryzae and supports a sucrose-mediated priming of defense responses in PRms rice plants which results in broad-spectrum disease resistance. Finally, it should be noted that, in our studies, we consistently used rice plants at the three- to four-leaf stage as the model system to study pathogen-induced priming, sucrose content, and sucrose responsiveness of defense genes. An interesting issue to address would be to determine whether the sucrose- mediated effect observed in the expression of defense genes in leaves of young rice plants is a factor that contributes to resistance as rice plants mature.

On the other hand, it has long been noted that the level of sugars increases in tissues during infection by viruses (Shalitin and Wolf 2000; Watson and Watson 1951). In this respect, it is reasonable to assume that plants have evolved a mechanism to modulate their sucrose levels in response to pathogen attack and use altered sucrose levels as a signal to activate defense reactions. In this context, our results suggest that sucrose acts as an endogenous molecular signal for induction of defense responses in rice plants. Better knowledge of the defense mechanisms mediated by sucrose could provide valuable insights for generating crop cultivars with an enhanced defensive capacity against pathogens.

To conclude, the observed resistance to both fungal and bacterial pathogens by expression of the PRms gene, this gene being not an antifungal gene, represents a major improvement compared with results from transgenic expression of other defense-related genes in rice. Physiologically, PRms rice plants exhibit an enhanced defensive capacity against potential invaders and provides an efficient mechanism to obtain broadspectrum protection against pathogens. PRms can be considered a useful alternative for broad-spectrum protection of rice plants against diseases because the rice cultivar used in transformation is an important Mediterranean cultivar. However, field evaluations of transgenic lines are needed to confirm these results. These findings also have a bearing on future biotechnological attempts to improve plant resistance to pathogens in other crops.

\section{MATERIALS AND METHODS}

\section{Plant, bacterial, and fungal material.}

Transformation was carried out using the Mediterranean elite japonica rice (O. sativa L.) cv. Senia. Fungi M. oryzae (PR09 isolate, CIRAD collection, Montpellier, France), F. verticillioides, and $H$. oryzae (isolates collected from rice plants in Spain and supplied by the Servei de Protecció dels Vegetals, Generalitat de Catalunya) were grown on rice flour medium (rice flour at $20 \mathrm{~g} / \mathrm{liter}$, agar at $15 \mathrm{~g} / \mathrm{liter}$, and yeast extract at $2.5 \mathrm{~g} /$ liter). Spores were collected by adding sterile water to the surface of the mycelium. After filtration, spores were adjusted to the appropriate concentration with sterile water using a Bürker counting chamber. E. chrysanthemi A3937 (provided by P. Rodríguez-Palenzuela, Universidad Politécnica, Madrid) was grown in King's medium overnight and its concentration determined spectrophotometrically. Plants were grown at $27 \pm$ $2^{\circ} \mathrm{C}$ under a photoperiod of $18 \mathrm{~h}$ of light and $6 \mathrm{~h}$ of dark.

\section{Construction of the plant expression vector and rice transformation.}

The PRms cDNA sequence (Casacuberta et al. 1991) was cloned into a pUC19 plasmid under the control of the 35SCaMV promoter and the nos terminator. The entire DNA fragment containing the $35 S C a M V$ promoter, coding sequence, and terminator was PCR amplified using the Expand High Fidelity PCR system (Roche, Darnstadt, Germany) and inserted into the SmaI-digested pCAMBIA1301 vector (Cambia, Camberra, Australia) to obtain the pCAMBIA35SCaMV:PRms:nos construct. The nucleotide sequence of the plant expression vector was verified by nucleotide sequencing.

The expression vector construct was transferred to the $A$. $t u$ mefaciens EHA105 strain (Hood et al. 1993). The parent pCAMBIA 1301 vector already contained the hptII (hygromycin phosphotransferase) gene encoding hygromycin resistance in the T-DNA region. Transgenic rice lines expressing the 
PRms gene were produced by Agrobacterium-mediated transformation of embryogenic callus derived from mature embryos as described by Pons and associates (2000).

\section{DNA gel blot analysis.}

DNA was extracted from leaves of rice plants according to the method of Murray and Thompson (1980) but using MATAB (0.1 M Tris HCl, pH 8.0, 1.4 M NaCl, 20 mM EDTA, $2 \%$ MATAB, $1 \%$ PEG 6000 , and $0.5 \%$ sodium sulphite) as the extraction buffer. DNAs were electrophoresed on $0.8 \%$ agarose gels, transferred to nylon membranes (Hybond-N; Amersham, Bucks, U.K.) and hybridized to ${ }^{32} \mathrm{P}$-labeled DNA probes. Hybridization was carried out in $40 \%$ formamide, $0.25 \mathrm{M}$ phosphate-buffered saline (PBS) $(1 \times \mathrm{PBS}, 50 \mathrm{mM}$ Na-phosphate, $\mathrm{pH} 7.5,0.15 \mathrm{M} \mathrm{NaCl}$ ), 7\% sodium dodecyl sulfate (SDS), and $10 \%$ PEGs containing salmon sperm DNA at $100 \mu \mathrm{g} / \mathrm{ml}$, at $42^{\circ} \mathrm{C}$. Membranes were washed to $3 \times \mathrm{SSC}(1 \times \mathrm{SSC}$ is $0.15 \mathrm{M}$ $\mathrm{NaCl}$ plus $0.015 \mathrm{M}$ sodium citrate) and $0.5 \% \mathrm{SDS}$ at $65^{\circ} \mathrm{C}$.

\section{RNA isolation and RT-PCR.}

Total RNA was isolated from leaves of soil-grown plants at the two- to three-leaf stage using TRIzol reagent (Invitrogen, Life Technologies, Basel, Switzerland) instructions. For RTPCR of the rice defense genes, total RNA was extracted from leaves at different times after fungal inoculation $(6,9,12,24$, and $48 \mathrm{~h}$ ). For each timepoint, leaves from eight individual plants were collected. The first cDNA was synthesized from DNase-treated total RNA $(1 \mu \mathrm{g})$ with M-MLV Reverse Transcriptase (Invitrogen). Aliquots of the resulting RT reaction product were used as the template for PCR analysis. Primers used for amplification reactions were as follows: OsPR-1a (accession number AJ278436), 5'-GGAAGTACGGCGAGAACA TC-3' and 5'-GGCGAGTAGTTGCAGGTG-3'; $O s P R-1 b$ (accession number U89895), 5'-CTTGGCGAGAACCTCTTCT G-3' and 5'-GCCGGCTTATAGTTGCATGT-3'; OsPR5 (accession number U77656), 5'-CAGTACTGCTGCACCGGCTC-3' and 5'-ACATCGATCAGATGCCAGCTAA-3'; Scil (PR6 accession number AY878693), 5'-GGCCAAGAAGGTGATTCTC AAGGAC-3' and 5'-ACAGCAGCATCGCTACTAACCA-3'; PBZ1 (accession number D38170), 5'-CCGGGCACCATCTAC ACC-3' and 5'-CCTCGATCATCTTGAGCATGC-3'; POX22.3 (accession number AF014467), 5'-CGACATCCTCGCCGTCG CC-3' and 5'-CTGTCCCTGAAGTTCTGGCAC; OsPAL (accession number XM466845), 5'-TTCTATACAACAACGG GCTTCC 3' and 5'-CCTGGAGGAGATGAGACCAA 3'; and OsNH1 (accession number AY923983), 5'-AGGTGGATTTGC ACCAGAACC-3' and 5'-TGAAAGAAGGGACCCACAAC. The control of the rice actin 1 gene (accession number X16280) was performed using the primers 5'-CGACGAGTCTGACCC ATCCA-3' and 5'-GTACCCGCATCAGGCATCTG-3'. Three independent RT-PCR reactions for the three PRms lines 15, 17, and 26 , were carried out.

\section{Preparation of protein extracts and immunoblotting.}

Protein extracts were prepared from leaves of transgenic and control plants. Plant material was frozen in liquid nitrogen and pulverized. Leaf proteins then were extracted by using $84 \mathrm{mM}$ citric acid, $30 \mathrm{mM} \mathrm{Na} 2 \mathrm{HPO}_{4}, \mathrm{pH}$ 2.8, $10 \mathrm{mM}$ EDTA, $14 \mathrm{mM}$ $\beta$-mercaptoethanol, and $6 \mathrm{mM}$ ascorbic acid as the extraction buffer (Murillo et al. 1997). As a control, protein extracts were prepared from germinating embryos that had been inoculated with $F$. verticillioides spores for 2 days. All protein concentrations were determined using the Bradford method (1976), using the Bio-Rad dye reagent and bovine serume albumen as a standard.

Proteins were separated by SDS polyacrylamide gel electrophoresis in $12.5 \%$ acrylamide gels in a Bio-Rad minigel system
(Laemmli 1970) and blotted onto nitrocellulose membranes. Immunoblots were carried out essentially according to the procedure of Towbin and associates (1979). The PRms was detected with a polyclonal anti-PRms antiserum that specifically recognized PRms (Murillo et al. 1997). Blots were incubated for 60 min at room temperature with the anti-PRms antiserum (diluted 1:1000), followed by incubation with alkaline phosphataseconjugated anti-rabbit immunoglobulin $\mathrm{G}$ antibodies (Sigma, Steinheim, Germany). The color substrates nitro blue tetrazolium salt and 5-bromo-4-chloro-3-indolyl phosphate were used for detection of serological reactions.

\section{Determination of sucrose content.}

Leaves from control and PRms plants at the four-leaf stage were collected and immediately frozen. Samples were pulverized in the presence of liquid nitrogen and extracted with $80 \%$ ethanol (10 mM HEPES, $\mathrm{pH} 7.4,1 \mathrm{ml} / \mathrm{g}$ fresh weight) at $80^{\circ} \mathrm{C}$ for $2 \mathrm{~h}$. The samples were centrifuged at $10,000 \mathrm{rpm}$ for 30 min at room temperature and the supernatant was used for determination of sucrose following instructions from the supplier (Roche).

\section{Disease resistance assays with fungal pathogens.}

To test resistance of $P R m s$ rice plants to the blast fungus $M$. oryzae infection, the detached leaf assay (Coca et al. 2004) initially was carried out. Briefly, the second leaf of 2-week-old soil-grown rice plants was placed into plate dishes with $1 \%$ $\mathrm{wt} / \mathrm{vol}$ water agar containing kinetine at $2 \mathrm{mg} / \mathrm{liter}$. Whatmann filter paper discs saturated with an $M$. oryzae spore suspension at the appropriate concentration were placed onto the upper face of the leaf for $36 \mathrm{~h}$ and then removed. The inoculated leaves were maintained under high humidity conditions for the required period of time. Development of disease symptoms with time was followed. Three independent T2 homozygous PRms lines and at least 36 plants for each line were assayed. Disease severity was inferred from the lesion size developed at the inoculated spots on the leaves after 7 days of infection. Lesion size was scored on three leaves and three inoculation sites each $\left(3 \times 10^{6}\right.$ spores $\left./ \mathrm{ml}\right)$, and three plants per each transgenic line and wild-type plants. Microscopical analyses of the interaction sites by bright-field and fluorescence microscopy was carried out as previously described (Jarosch et al. 2005). Leaves collected from $M$. oryzae-infected leaves $\left(3 \times 10^{6}\right.$ spores $/ \mathrm{ml}$ ) using the detached leaf assay were analyzed at 15 , 24 , and $36 \mathrm{~h}$ after inoculation. Host cell autofluorescence was viewed by fluorescent microscopy (excitation filter 395 to 440 $\mathrm{nm}$, dichroic mirror $460 \mathrm{~nm}$, barrier filter $470 \mathrm{~nm}$ ) (Zeiss Axiophot microscope; Carl Zeiss, Thornwood, NY, U.S.A.). In all, 100 infection sites were examined.

Evaluation of resistance to blast of PRms-expressing rice plants also was assayed by spraying soil-grown control and transgenic rice plants with $M$. oryzae spores. Plants at the three-leaf stage were sprayed with a spore suspension $\left(10^{4}\right.$ spores $/ \mathrm{ml}$, containing $0.02 \% \mathrm{vol} / \mathrm{vol}$ Tween-20) until leaves were covered with fine droplets. Following inoculation, the plants were maintained in a dew chamber with $95 \%$ relative humidity. Development of symptoms was monitored visually. Disease severity in wild-type and PRms lines (lines 15, 17, and 26; 24 plants per line) also was scored at 7 days post inoculation using the 1-to-6 scale (Silué et al. 1992).

Resistance to $H$. oryzae was analyzed using the detached leaf assay as described for $M$. oryzae. For assays with $F$. verticillioides, seed of PRms and wild-type plants were pregerminated for $24 \mathrm{~h}$ on sterile filter-watered paper and then inoculated with a suspension of $F$. verticillioides spores at different concentrations $\left(10^{2}, 10^{4}, 10^{6}\right.$, and $10^{8}$ spores $\left./ \mathrm{ml}\right)$, or with sterile water. Seed were allowed to continue germination. 
In this study, trypan blue staining was used to confirm fungal colonization. For this, the fungal-inoculated leaves were fixed with formaldehyde (ethanol/formaldehyde/acetic acid, $80: 3.5: 5 \mathrm{vol} / \mathrm{vol}$ ) by vacuum infiltration for $1 \mathrm{~h}$ at room temperature. After one change, the tissue was kept in the fixation solution overnight. The plant material then was stained with lactophenol blue solution for $6 \mathrm{~h}$ at room temperature, washed with water, and observed with a Zeiss Axiophot microscope (Carl Zeiss) under bright-field illumination.

\section{Disease resistance assays with $E$. chrysanthemi.}

For assays with E. chrysanthemi, seed of PRms and wildtype plants were pregerminated in Murashige-Skoog (MS) liquid medium (without sucrose) for $24 \mathrm{~h}$. Seedlings (12 per line) were inoculated with $100 \mu \mathrm{l}$ of a bacterial culture containing $10^{6} \mathrm{CFU}$ by vacuum infiltration. After bacterial infiltration, seedlings were allowed to continue germination for 7 days.

\section{Sucrose treatment of rice plants.}

To study sucrose responsiveness of defense rice genes in rice, seeds of wild-type plants were germinated in pots containing MS medium with no sucrose $(30 \mathrm{ml}$ of $\mathrm{MS}$ and $0.5 \%$ gelrite) for 7 days. Treatments were performed by adding a sucrose, mannitol, or PEG-containing MS liquid medium to the pots at a final concentration of $0.3 \mathrm{M}$ sucrose, $0.3 \mathrm{M}$ mannitol, or 7\% PEG-8000 (wt/vol). Plantlets were collected at 6 and $9 \mathrm{~h}$ after the onset of treatment, washed with water, and quickly frozen in liquid nitrogen. Each timepoint represents at least 10 plantlets.

To assess protection afforded by treatment with sucrose, soil-grown wild-type Senia plants at the three- to four-leaf stage were watered and sprayed with a $0.3 \mathrm{M}$ sucrose or $0.3 \mathrm{M}$ mannitol or $7 \%$ PEG-8000 (wt/vol) solution or sterile water for $24 \mathrm{~h}$. Plants then were infected by spraying with a suspension of $M$. oryzae spores $\left(10^{4}\right.$ spores $\left./ \mathrm{ml}\right)$ as described above.

\section{ACKNOWLEDGMENTS}

M. Coca is a researcher from the Ministerio de Ciencia y Tecnología (MCyT, Ramón y Cajal). S. Campo was a recipient of a predoctoral fellowship from MCyT. We thank P. Rodriguez-Palenzuela for providing us with the E. chrysanthemi culture. We are grateful to I. Murillo for collaboration in parts of this work, P. Fontanet for taking care of the greenhouse plants, and A. Sanchez for picture assistance. This work was supported by grants from the Ministerio de Ciencia y Tecnología, BIO2003-04936-C02-01 and BIO2006-05583 to B. San Segundo, and BIO2003-04936-C02-02 to J. Messeguer. We also thank the Xarxa de Referència en Biotecnología for substantial support.

\section{LITERATURE CITED}

Agrawal, G. K., Rakwal, R., Jwa, N.-S., and Agrawal, V. P. 2001. Signalling molecules and blast pathogen attack activates rice OsPRla an $O s P R 1 b$ genes: a model illustrating components participating during defense/stress response. Plant Physiol. Biochem. 39:1095-1103.

Bradford, M. 1976. A rapid and sensitive method for the quantification of microgram quantities utilizing the principle of protein-dye binding, Anal. Biochem. 72:248-254.

Cao, H., Bowling, S. A., Gordon, A. S., and Dong, X. 1994. Characterization of an Arabidopsis mutant that is nonresponsive to inducers of systemic acquired resistance. Plant Cell 6(11):1583-1592.

Casacuberta, J. M., Puigdomènech, P., and San Segundo, B. 1991. A gene coding for a basic pathogenesis-related (PR-like) protein from Zea mays. Molecular cloning and induction by a fungus (Fusarium moniliforme) in germinating maize seeds. Plant Mol. Biol. 16:527-536.

Casacuberta, J. M., Raventós, D., Puigdomènech, P., and San Segundo, B. 1992. Expression of the gene encoding the PR-like protein PRms in germinating maize embryos. Mol. Gen. Genet. 234:97-104.

Chern, M. S., Fitzgerald, H. A., Yadav, R. C., Canlas, P. E., Dong, X., and Ronald, P. C. 2001. Evidence for a disease-resistance pathway in rice similar to the NPR1-mediated signaling pathway in Arabidopsis. Plant J. 27(2):101-113.

Chern, M. S., Fitzgerald, H. A., Canlas, P. E., Navarre, D. A., and Ronald, P. C. 2005. Overexpression of a rice NPR1 homologue leads to constitutive activation of defense response and hypersensitivity to light. Mol. Plant-Microbe Interact. 18:511-520.

Chittoor, J. M., Leach, J. E., and White, F. F. 1997. Differential induction of a peroxidase gene family during infection of rice by Xanthomonas oryzae pv. oryzae. Mol. Plant-Microbe Interact. 10(7):861-871.

Coca, M., Bortolotti, C., Rufat, M., Peñas, G., Eritja, R., Tharreau, D., Martinez del Pozo, A., Messeguer, J., and San Segundo, B. 2004. Transgenic rice plants expressing the antifungal AFP protein from Aspergillus giganteus show enhanced resistance to the rice blast fungus Magnaporthe grisea. Plant Mol. Biol. 54:245-259.

Datta, S., Muthukrishnan, S., and Datta, S. K.1999. Expression and function of PR proteins in transgenic plants. Pages 261-77 in: PathogenesisRelated Proteins in Plants. S. K. Datta and S. Muthukrishnan, eds. CRC Press, New York.

Dong, X. 2004. NPR1, all things considered. Curr. Opin. Plant Biol. 7:547-552.

Goto, M. 1979. Dissemination of Erwinia chrysantemy, the causal organism of bacterial foot rot of rice. Plant Dis. Rep. 63:100-103.

Hammond-Kosack, K. E., and Jones, J. D. G. 1996. Resistance genedependent plant defense responses. Plant Cell 8:1773-1791.

Hood, E. E., Gelvin, S. B., Melchers, L. S., and Hoekema, A. 1993. New Agrobacterium helper plasmids for gene transfer to plants. Transgenic Res. 2:208-218.

Iwai, T., Kaku, H., Honkura, R., Nakamura, S., Ochiai, H., Sasaki, T., and Ohashi, Y. 2002. Enhanced resistance to seed-transmitted bacterial diseases in transgenic rice plants overproducing an oat cell-wall-bound thionin. Mol. Plant-Microbe Interact. 15:515-521.

Jach, G., Gornhardt, B., Mundy, J., Logemann, J., Pinsdorf E., Leah, R., Schell, J., and Maas, C. 1995. Enhanced quantitative resistance against fungal disease by combinatorial expression of different barley antifungal proteins in transgenic tobacco. Plant J. 8:97-103.

Jarosch, B., Collins, N. C., Zellerhoff, N., and Schaffrath, U. 2005. RAR1, ROR1, and the actin cytoskeleton contribute to basal resistance to Magnaporthe grisea in barley. Mol. Plant-Microbe Interact. 18(5):397-404.

Jwa, N.-S., Agrawal, G. K., Tamogami, S., Yonekura, M., Han, O., Iwahashi, H., and Rakwal, R. 2006. Role of defense/stress-related marker genes, proteins and secondary metabolites in defining rice selfdefense mechanisms. Plant Physiol. Biochem. 44:261-273.

Koga, H. 1994. Hypersensitive death, autofluorescence, and ultrastructural changes in cells of leaf sheaths of susceptible and resitant near-isogenic lines of rice $\left(\mathrm{Pi}-\mathrm{z}^{\mathrm{t}}\right)$ in relation to penetration and growth of Pyricularia oryzae. Can. J. Bot. 72:1463-1477.

Kogel, K. H., and Langen, G. 2005. Induced disease resistance and gene expression in cereals. Cell. Microbiol. 7(11):1555-1564.

Kohler, A., Schwindling, S., and Conrath, U. 2002. Benzothiadiazoleinduced priming for potentiated responses to pathogen infection, wounding, and infiltration of water into leaves requires the NPR1/NIM1 gene in Arabidopsis. Plant Physiol. 128:1046-1056.

Laemmli, U. K. 1970. Cleavage of structural proteins during the assembly of the head of bacteriophage T4. Nature 227:680-685.

McGee, J. D., Hamer, J. E., and Hodges, T. K. 2001. Characterization of a PR10 pathogenesis-related gene family induced in rice during infection with Magnaporthe oryzae. Mol. Plant-Microbe Interact. 14(7):877886.

Midoh, N., and Iwata, M. 1996. Cloning and characterization of a probenazole-inducible gene for an intracellular pathogenesis-related protein in rice. Plant Cell Physiol. 37(1):9-18.

Mur, L., Naylor, G., Warner, S., Sugars, J. M., White, R. F., and Draper, J. 1996. Salicylic acid potentiates defence gene expression in tissue exhibiting acquired resistance to pathogen attack. Plant J. 9(4):559-571.

Murillo, I., Cavallarin, L., and San Segundo, B. 1997. The maize pathogenesis-related PRms protein localizes to plasmodesmata in maize radicles. Plant Cell 9:145-156.

Murillo, I., Roca, R., Bortolotti, C., and San Segundo, B. 2003. Engineering photoassimilate partitioning in tobacco plants improves growth and productivity and provides pathogen resistance. Plant J. 36:330-341.

Murray, M. G., and Thompson, W. F. 1980. Rapid isolation of high molecular weight plant DNA. Nucleic Acid Res. 8:4321-4325.

Nelson, P. E., Desjardins, A. E., and Plattner, R. D. 1993. Fumonisins, mycotoxins produced by Fusarium species: biology, chemistry and significance. Annu. Rev. Phytopathol. 31:233-252.

Ou, S. H. 1985. Rice Diseases, 2nd ed. Commonwealth Mycological Institute. Kew, Surrey, England.

Pons, M. J., Marfà, V., Melé, E., and Messeguer, J. 2000. Regeneration and genetic transformation of Spanish rice cultivars using mature embryos. Euphyta 114:117-122. 
Seifert, K. A., Aoki, T., Baayen, R. P., Brayford, D., Burgess, L. W., Chulze, S., Gams, W., Geiser, D., de Gruyter, J., Leslie, J. F., Logrieco, A., Marasas, W. F. O., Nirenberg, H. I., O'Donnell, K., Rheeder, J. P., Samuels, G. J., Summerell, B. A., Thrane, U., and Waalwijk, C. 2003. The name Fusarium moniliforme should no longer be used. Mycol. Res. 107:643-644

Shalitin, D., and Wolf, S. 2000. Cucumber mosaic virus infection affects sugar transport in melon plants. Plant Physiol. 123(2):597-604.

Silué, D., Nottéghem, J. L., and Tharreau, D. 1992. Evidence of a genefor-gene relationship in the Oryza sativa-Magnaporthe grisea pathosystem. Phytopathology 82:577-580.

Staswick, P. E., and Tiryaki, I. 2004. The oxylipin signal jasmonic acid is activated by an enzyme that conjugates it to isoleucine in Arabidopsis. Plant Cell 16:2117-2127.

Thulke, O., and Conrath, U. 1998. Salicylic acid has a dual role in the activation of defence-related genes in parsley. Plant J. 14(1):35-42.

Towbin, H., Staehelin, T., and Gordon, J. 1979. Electrophoretic transfer of proteins from polyacrylamide gels to nitrocellulose sheets: Procedures and some applications, Proc. Natl. Acad. Sci. U.S.A. 76:43504354.

Van Loon, L. C., Rep, M., and Pieterse, C. M. J. 2006. Significance of inducible defense-related proteins in infected plants. Annu. Rev. Phytopathol. 44:7.1-7.28

Velazhahan, R., Chen-Cole, K., Anuratha, C. S., and Muthukrishnan, S. 1998. Induction of thaumatin-like proteins (TLPs) in Rhizoctonia solani-infected rice and characterization of two new cDNA clones. Physiol. Plant. 102:21-28.

Watson, M. A., and Watson, D. J. 1951. The effect of infection with beet mosaic viruses on the carbohydrate content of sugar-beet leaves, and on translocation. Ann. Appl. Bot. 38:276-289.

Zhu, Q., Maher, E. A., Masoud, S., Dixon, R. A., and Lamb, C. J. 1994. Enhanced protection against fungal attack by constitutive co-expression of chitinase and glucanase genes in transgenic tobacco. Bio/Technology 12:807-812. 